\title{
Comparisons of Urinary Creatinine, Skeletal Muscle Mass, and Indices of Muscle Protein Catabolism in Rats Fed ad libitum, with Restricted Food Intake, and Deprived of Food
}

\author{
Toru Rikimaru, Tomoko Oozeki, Mineko ICHIKAWA, \\ Hidemichi EBISAWA, and Yoshiaki FujITA ${ }^{1}$ \\ Nutrition Research Laboratory, Tokyo Metropolitan Institute of \\ Gerontology, Itabashi-ku, Tokyo 173, Japan
}

(Received October 7, 1988)

\begin{abstract}
Summary Urinary excretions of creatinine (CR) and 3-methylhistidine (3-MeHis), and skeletal muscle mass (SKM) were measured in rats (male, Wistar, weighing about $290 \mathrm{~g}$ ) fed a $20 \%$ casein diet ad libitum, rats restricted to $70 \%$ of the food intake of the ad libitum group, and rats deprived of food for 20 days. At the same time, catabolic rates of muscle protein derived from 3-MeHis/CR, 3-MeHis/BW, and 3-MeHis/SKM were compared. The CR/SKM ratio in the energy-restricted group was similar to the ad libitum group, while the ratio was higher in the food-deprived group than in the other two groups. This means that CR excretion was promoted per unit of skeletal muscle mass by food deprivation. These results indicate that CR excretion can be an index for SKM under the condition of energy restriction, but not under the condition of food deprivation. The present data also suggest that it is possible to use the 3-MeHis/CR ratio instead of 3-MeHis/SKM which is the most reliable index of the three indices, under the condition of mild energy restriction. In food deprivation, however, the $3-\mathrm{MeHis} / \mathrm{CR}$ data tended to underestimate the catabolic rate of muscle protein compared with the 3-MeHis/SKM data. The 3-MeHis/BW data was similar to the 3-MeHis/SKM with all dietary conditions. The catabolic rate of muscle protein was constant or decreased very slightly under ad libitum feeding, decreased slightly in energy restriction, and increased drastically with food deprivation.
\end{abstract}

Key Words urinary creatinine, skeletal muscle mass, 3-methylhistidine, muscle protein catabolism, energy restriction, food deprivation

Recent studies observing urinary 3-methylhistidine (3-MeHis) have contributed considerably to defining the influence of diet on muscle protein catabolism $(1,2)$. The catabolic rate of muscle protein can be estimated by measuring urinary 3-MeHis,

1 力丸 徹, 大関知子, 市川みね子, 海老沢秀道, 藤田美明 
concentration of 3-MeHis in muscle protein and the total amount of muscle protein (3). One of the reliable indices for the catabolic rate can be represented as the ratio of daily urinary excretion of 3-MeHis to the total amount of skeletal muscle mass (3-MeHis/SKM). However, it is often represented as the ratio of 3-MeHis excretion to creatinine excretion (3-MeHis/CR) (4). This is bcause CR excretion has been generalized to be a reliable approximate parameter for total muscle mass $(5,6)$. But urinary $\mathrm{CR}$ excretion is not always proportional to the total amount of skeletal muscle mass (SKM) under different conditions (7). Sometimes where CR excretion is not parallel to skeletal muscle mass, the catabolic rates of muscle protein obtained as the 3-MeHis/CR ratio give varying results.

Thus in the present study we determined the urinary CR and 3-MeHis excretions and the total amount of SKM in rats under extremely different dietary conditions, i.e. ad libitum feeding, food restriction, and food deprivation, and then compared 3-MeHis/CR and 3-MeHis/SKM ratios.

\section{MATERIALS AND METHODS}

Animals and diet. Male SPF Wistar rats, weighing about $290 \mathrm{~g}$, were used for this study and divided into four groups of 11 or 12 animals. They were kept on a standard diet containing $20 \%$ casein for one week. Then one of four groups was sacrificed as an age-control. Thereafter, the other three groups were deprived of

Table 1. Composition of diet.

\begin{tabular}{lc}
\hline Ingredient & Amount (\%) \\
\hline Casein $^{1}$ & 20.0 \\
Sucrose $^{1}$ & 20.9 \\
$_{\text {-Cornstarch }}{ }^{1}$ & 41.8 \\
Corn oil $^{1}$ & 5.0 \\
Cellulose powder $^{1}$ & 5.0 \\
Vitamin mixture $^{2}$ & 2.0 \\
Mineral mixture $^{3}$ & 5.0 \\
L-Methionine $^{4}$ & 0.3 \\
\hline
\end{tabular}

${ }^{1}$ From Oriental Yeast, Tokyo. ${ }^{2}$ From Oriental Yeast, Tokyo. Contents per $100 \mathrm{~g}$ of diet: retinyl acetate, $1,000 \mathrm{IU}$; cholecalciferol, $200 \mathrm{IU}$; DL- $\alpha$-tocopheryl acetate, $10.0 \mathrm{mg}$; menadione, $10.4 \mathrm{mg}$; thiamine $\cdot \mathrm{HCl}, 2.4 \mathrm{mg}$; riboflavin, $8.0 \mathrm{mg}$, pyridoxine $\cdot \mathrm{HCl}, 1.6 \mathrm{mg}$; cyanocobalamine, $1.0 \mu \mathrm{g}$; D-biotin, $40 \mu \mathrm{g}$; folic acid, $0.4 \mathrm{mg}$; D-calcium pantothenate, $10.0 \mathrm{mg}$; nicotinic acid, $12.0 \mathrm{mg}$ (these 12 ingredients are standard vitamins for rats and mice as reported by the American Institute of Nutrition (8)); ascrobic acid, $60 \mathrm{mg}$; $p$-aminobenzoic acid, $10.0 \mathrm{mg}$; inositol, $12.0 \mathrm{mg}$; and choline chloride, $400 \mathrm{mg}$. ${ }^{3}$ From Oriental Yeast, Tokyo. Contents per $100 \mathrm{~g}$ of diet: $\mathrm{CaHPO}_{4} \cdot \mathrm{H}_{2} \mathrm{O}, 699 \mathrm{mg} ; \mathrm{KH}_{2} \mathrm{PO}_{4}$, $1,235 \mathrm{mg}$; $\mathrm{NaHPO}_{4}, 449 \mathrm{mg}$; $\mathrm{NaCl}, 224 \mathrm{mg}$; calcium lactate, $1,684 \mathrm{mg}$; ferric citrate, $153 \mathrm{mg} ; \mathrm{MgSO}_{4}, 344 \mathrm{mg} ; \mathrm{ZnCO}_{3}, 5.28 \mu \mathrm{g} ; \mathrm{MnSO}_{4} \cdot 6 \mathrm{H}_{2} \mathrm{O}, 5.76 \mu \mathrm{g} ; \mathrm{CuSO}_{4} \cdot 5 \mathrm{H}_{2} \mathrm{O}$, $1.44 \mu \mathrm{g}$; and KI, $0.48 \mu \mathrm{g} .{ }^{4}$ From Wako Pure Chemical Industries, Osaka. 
food, fed the standard diet ad libitum, or fed an energy-restricted diet for 20 days. The food-restricted group was given $12 \mathrm{~g}$ of the $20 \%$ casein diet. Composition of the diet is shown in Table 1. The animals were kept in an air-conditioned room at $22 \pm 2^{\circ} \mathrm{C}$ with a 12 -h light period from 8:00 a.m. to 8:00 p.m. Food intake and body weight were measured every day at 10:00 a.m. For determination of urinary excretions of $\mathrm{CR}$ and 3-MeHis, their total urine was collected for three 3-day periods: the final 3 days of the control period, days 8 through 10 , and days 18 through 20 of the experimental period. All the rats were sacrificed on day 20 and the gastrocnemius muscle was removed and weighed.

Analyses. Half of the rats in each group were used for determining body composition. The carcasses, from which viscera were removed, were chopped up in a frozen state using an electric mincer. Portions of the minced carcass were weighed precisely in aliquots ranging from 50 to $100 \mathrm{~g}$ and dried at $105^{\circ} \mathrm{C}$ for $24 \mathrm{~h}$. The moisture percentage was then calculated. The dried carcasses were ground again and the resulting portions were used for determining fat, protein, and ash contents. Protein content was obtained by multiplying 6.25 , the nitrogen coefficient, by the nitrogen content determined by the Kjeldahl method. Fat content was determined using a lipid-extract apparatus (EX-Fat, Nihon Zeneraru Ltd., Tokyo). Ash content was determined by weighing the sample after igniting it in a muffle at $550^{\circ} \mathrm{C}$ for $48 \mathrm{~h}$.

The remaining rats in each group were used for measuring skeletal muscle mass. The skin with hair and adipose tissue as well as viscera were thoroughly removed from the carcass, and the rest of the carcass was heated at $120^{\circ} \mathrm{C}$ for $20 \mathrm{~min}$ in an autoclave. The muscle was then separated from the skeleton. The total weight of skeletal muscle was calculated as the difference between the weights of the carcass without viscera, skin and adipose tissue and the skeleton.

Urinary creatinine was determined by the Folin's method with modifications by Koishi (9), and urinary 3-methylhistidine was analyzed using an automatic amino acid analyzer (Model 6AH, Nihon Denshi Ltd., Tokyo). For analyzing urinary 3 -methylhistidine, a urine sample was heated with an equal volume of $12 \mathrm{~N} \mathrm{HCl}$ at $110^{\circ} \mathrm{C}$ for $2 \mathrm{~h}$ to convert $n$-acetyl-3-methylhistidine to 3 -methylhistidine (10).

Pearson correlation coefficients were computed to assess the relationship among the total amount of skeletal muscle mass and other relevant variables. The differences between the age-control group and the other three groups were examined using Student's $t$-test. The differences between the values of the first period and those of the second and third periods in each group were examined by paired Student's $t$-test. The data of the three experimental groups were subjected to one-way analysis of variance using Duncan's multiple range test with a significant level of $p<0.05$.

\section{RESULTS}

\section{Food intake and body weight}

Daily food intake of the ad lib. group averaged $17 \mathrm{~g}$ throughout the experi- 
mental period. The food-restricted group was given $12 \mathrm{~g}$ of the diet daily, which corresponded to about $70 \%$ of the food intake of the $a d$ lib. group. The body weight of the ad lib. group increased slightly, while the food-restricted group decreased somewhat, and that of the food-deprived group decreased drastically.

\section{Weight in skeletal muscle}

The final weight of the skeletal muscle was $132 \pm 5 \mathrm{~g}$ in the age-control group, $135 \pm 8 \mathrm{~g}$ in the ad lib. group, $128 \pm 4 \mathrm{~g}$ in the food-restricted group, and $78 \pm 5 \mathrm{~g}$ in the food-deprived group. The weights as a percentage of the body weight were $40.6 \pm 1.2,39.3 \pm 1.6,42.0 \pm 1.8$, and $45.4 \pm 2.1 \%$, respectively. The weight of the gastrocnemius muscle paralleled that of skeletal muscle, as shown in Fig. 1. Food restriction depressed increases in muscle weight, while food deprivation promoted
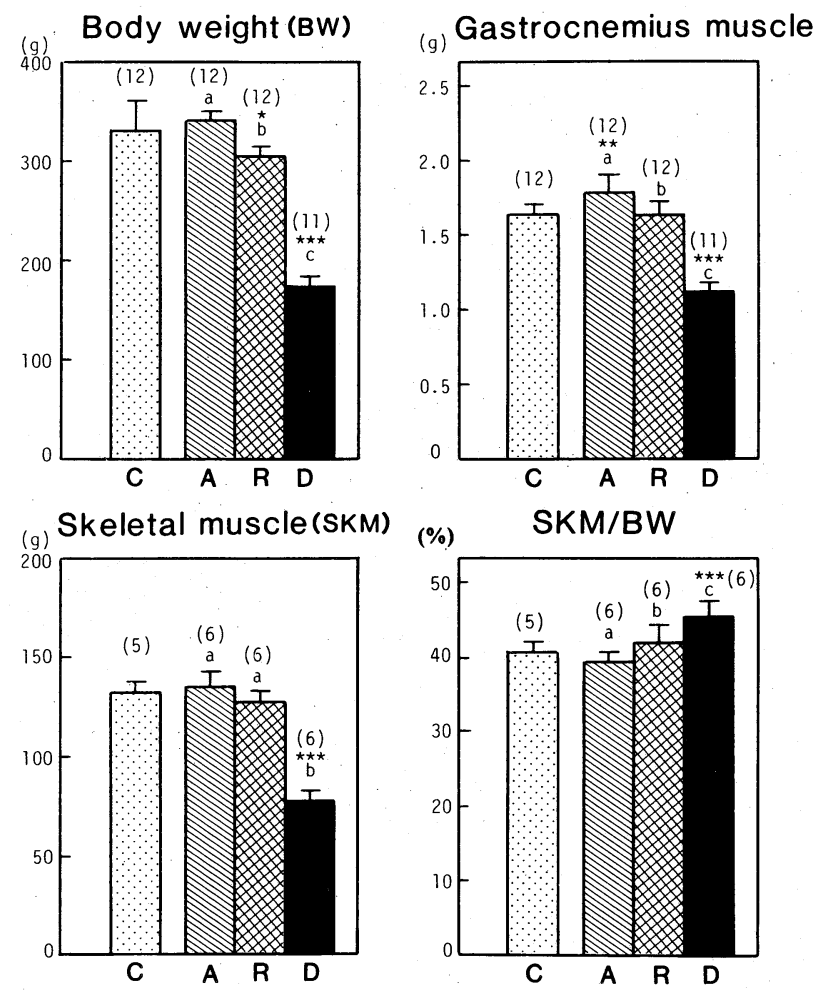

Fig. 1. Weights of body, gastrocnemius muscle, and total skeletal muscle mass in age-control rats (C) and ad libitum (A), food-restricted (R), and food-deprived(D) rats. Values are expressed as means \pm SD. Figures in parentheses are the number of the sample. Asterisks $\left(^{*}\right)$ indicate significant differences from the value of the control groups; ${ }^{*}, p<0.05 ;^{* *}, p<0.01 ;{ }^{* * *}, p<0.001$. In the three experimental groups, the values not sharing the same superscript letter are significantly different $(p<0.05)$. 
Table 2. Correlation of skeletal muscle mass with approximate parameters for skeletal muscle. $^{1}$

\begin{tabular}{llcc}
\hline & \multicolumn{2}{l}{ vs. Skeletal muscle mass } \\
& $(n)^{2}$ & $r^{3}$ & $p^{4}$ \\
\hline Body weight & $(23)$ & 0.980 & $<0.001$ \\
Carcass weight & $(23)$ & 0.978 & $<0.001$ \\
Gastrocnemius muscle & $(23)$ & 0.955 & $<0.001$ \\
Daily creatinine excretion & $(18)$ & 0.932 & $<0.001$ \\
\hline
\end{tabular}

${ }^{1}$ Calculated with data pooled together from each group. ${ }^{2}$ Number of samples.

${ }^{3}$ Pearson's correlation coefficient. ${ }^{4}$ Probability.

Table 3. Body composition.

\begin{tabular}{lcrrr}
\hline Groups & $\begin{array}{c}\text { Age-control } \\
(6)^{1}\end{array}$ & \multicolumn{1}{c}{$\begin{array}{c}\text { Ad lib. } \\
(6)\end{array}$} & $\begin{array}{c}\text { Restriction } \\
(6)\end{array}$ & $\begin{array}{c}\text { Deprivation } \\
(5)\end{array}$ \\
\hline Absolute amount $(\mathrm{g})$ & & & & \\
Water & $157.5 \pm 7.2^{2}$ & $166.2 \pm 6.4^{\mathrm{a}}$ & $152.3 \pm 5.9^{\mathrm{b}}$ & $99.3 \pm 6.2^{*, \mathrm{c}}$ \\
Protein & $52.5 \pm 3.6$ & $56.4 \pm 2.7^{\mathrm{a}}$ & $52.2 \pm 1.2^{\mathrm{b}}$ & $35.7 \pm 1.6^{*, \mathrm{c}}$ \\
Fat & $49.6 \pm 9.4$ & $50.4 \pm 4.9^{\mathrm{a}}$ & $41.8 \pm 4.6^{\mathrm{b}}$ & $3.4 \pm 2.8^{*, \mathrm{c}}$ \\
Ash & $8.4 \pm 0.8$ & $9.1 \pm 0.9^{\mathrm{a}}$ & $8.3 \pm 1.0^{\mathrm{a}}$ & $6.2 \pm 0.6^{*, \mathrm{~b}}$ \\
& & & & \\
Percentage (\%) & & & & \\
Water & $57.0 \pm 1.8$ & $56.7 \pm 1.5^{\mathrm{a}}$ & $58.2 \pm 1.7^{\mathrm{a}}$ & $67.3 \pm 1.1^{*, \mathrm{~b}}$ \\
Protein & $19.0 \pm 1.0$ & $19.2 \pm 0.7^{\mathrm{a}}$ & $20.0 \pm 0.6^{\mathrm{a}}$ & $24.2 \pm 1.0^{*, \mathrm{~b}}$ \\
Fat & $17.6 \pm 3.4$ & $17.2 \pm 1.6^{\mathrm{a}}$ & $16.0 \pm 1.8^{\mathrm{a}}$ & $2.2 \pm 1.8^{*, \mathrm{~b}}$ \\
Ash & $3.0 \pm 0.1$ & $3.1 \pm 1.6^{\mathrm{a}}$ & $3.2 \pm 0.4^{\mathrm{a}}$ & $4.2 \pm 0.6^{*, \mathrm{~b}}$ \\
\end{tabular}

${ }^{1}$ Number of samples. ${ }^{2}$ Means \pm SD. Asterisks $\left({ }^{*}\right)$ indicate significant differences from the values of the age-control groups. In the three experimental groups, the values not sharing the same superscript letter are significantly different $(p<0.05)$.

exhaustion of muscle mass. The weight of muscle mass showed a highly significant correlation with body weight, weight of the gastrocnemius muscle, and urinary creatinine excretion (Table 2). The skeletal muscle mass correlated more with body weight $(r=0.98, p<0.001)$ than with urinary creatinine excretion $(r=0.93, p<0.001)$.

\section{Body composition}

Body composition is shown in Table 3. The absolute amounts of respective body components increased in the ad lib. group, while those values decreased in the food-deprived rats. The values for food-restricted rats remained unchanged except that the absolute amount of fat decreased slightly. The percentages of each body component in the ad lib. group did not change during the whole period. In addition, 
these percentages in the food-restricted group were not significantly different from those of the ad lib. group, although the protein percentage tended to be slightly higher and the fat percentage to be slightly lower in the food-restricted group than in the ad lib. group. However, the food-deprived group showed a remarkable decrease in fat percentage and a consequent increase in the percentage of protein, water, and ash.

\section{Urinary creatinine excretion}

Urinary CR excretion increased slightly in the ad lib. group, remained constant in the food-restricted group, and decreased in the food-deprived group (Table 4). Urinary CR excretion is generally used as an approximate parameter of the amount of skeletal muscle mass. Therefore, the ratio of urinary CR excretion to total skeletal muscle (CR/SKM) is expected to be constant in any dietary condition. However, the ratio was higher in the food-deprived group than in the other two groups. There was no difference in this ratio between the energy-restricted group and the ad lib. group. Although the ratio of urinary $\mathrm{CR}$ to the weight of gastrocnemius muscle (CR/GCM) was almost the same in the three groups, the ratio of CR to body weight (CR/BW) significantly differed among the three groups. The $\mathrm{CR} / \mathrm{BW}$ ratio and the CR/SKM ratio were highest in the food-deprived group.

\section{Urinary 3-methylhistidine excretion}

Urinary 3-MeHis excretion is shown in Fig. 2. There was no significant

Table 4. Urinary creatinine excretion and its ratios to the weight of skeletal muscle mass and gastrocnemius muscle and body weight.

\begin{tabular}{|c|c|c|c|}
\hline Groups & Ad lib. & Restriction & Deprivation \\
\hline & $(12)^{1}$ & (12) & (11) \\
\hline \multicolumn{4}{|c|}{ Urinary creatinine $(\mathrm{mg} / \mathrm{d})$} \\
\hline 1st period ${ }^{2}$ & $9.17 \pm 0.51^{3}$ & $9.31 \pm 0.67$ & $9.35 \pm 0.47$ \\
\hline 2nd period & $9.47 \pm 0.51^{\mathrm{a}}$ & $9.49 \pm 0.52^{\mathrm{a}}$ & $8.37 \pm 0.35^{*, \mathrm{~b}}$ \\
\hline 3 rd period & $9.82 \pm 0.52^{*, a}$ & $9.40 \pm 0.54^{\mathrm{b}}$ & $6.39 \pm 0.34^{*, c}$ \\
\hline $\mathrm{CR} / \mathrm{GCM}^{4}(\mathrm{mg} / \mathrm{g})$ & $5.53 \pm 0.47$ & $5.73 \pm 0.39$ & $5.79 \pm 0.39$ \\
\hline $\mathrm{CR} / \mathrm{BW}^{5}(\mathrm{mg} / 100 \mathrm{~g})$ & $\begin{array}{c}2.88 \pm 0.16^{\mathrm{a}} \\
(6)\end{array}$ & $\begin{array}{c}3.08 \pm 0.15^{b} \\
(6)\end{array}$ & $\begin{array}{c}3.70 \pm 0.15^{c} \\
(6)\end{array}$ \\
\hline $\mathrm{CR} / \mathrm{SKM}^{6}(\mathrm{mg} / 100 \mathrm{~g})$ & $7.23 \pm 0.54^{\mathrm{a}}$ & $7.34 \pm 0.60^{\mathrm{a}}$ & $8.22 \pm 0.66^{\mathrm{b}}$ \\
\hline
\end{tabular}

${ }^{1}$ Number of samples. ${ }^{2}$ First period corresponds to the control period in which all the groups were fed a $20 \%$ casein diet ad libitum. ${ }^{3}$ Means \pm SD. Asterisks $\left({ }^{*}\right)$ indicate significant difference from the value of the first period $(p<0.05)$. In the three experimental groups, the values not sharing the same superscript letter are significantly different $(p<0.05) .{ }^{4}$ The ratio of daily urinary creatinine to the weight of gastrocnemius muscle at the third period. ${ }^{5}$ The ratio of daily urinary creatinine to body weight at the third period. ${ }^{6}$ The ratio of daily urinary creatinine to the weight of skeletal muscle mass at the third period. 

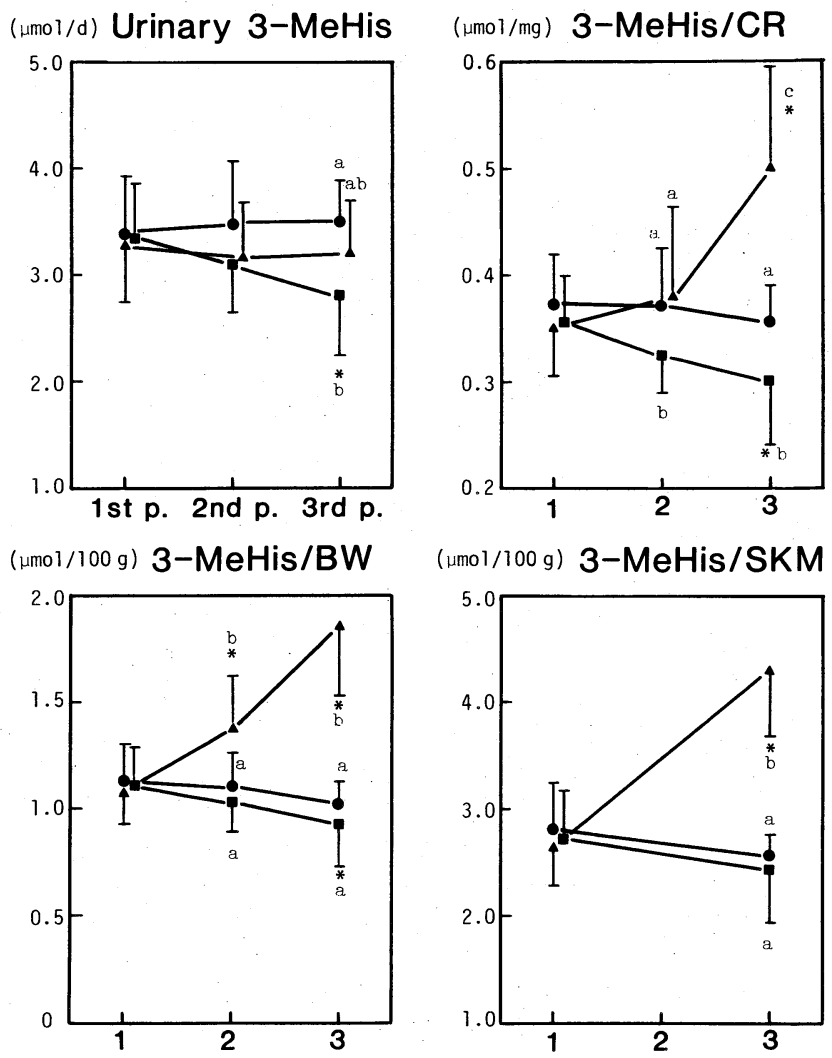

Fig. 2. Changes in urinary 3-MeHis, 3-MeHis/CR, 3-MeHis/BW, and 3-MeHis/SKM ratios during the experimental period in ad libitum ( $(\bullet)$, food-restricted (ם) and food-deprived ( $\Delta$ ) rats: 3-MeHis, urinary 3-methylhistidine; CR, urinary creatinine; BW, body weight; SKM, skeletal muscle mass. The values were expressed as means \pm SD for 10 to 12 samples, except for 5 to 6 samples for the data of 3-MeHis/SKM during the third period. Only the values of SKM during the control period were estimated by multiplying the body weight of that period by the SKM percentage in the rats sacrificed as a control group and these values were used for calculating the 3-MeHis/SKM ratio of the control period. Asterisks $(*)$ indicate significant differences from the values of the first period $(p<0.05)$. In three groups, the values in each period not sharing the same superscript letter are significantly different $(p<0.05)$.

difference in the absolute amount of daily urinary 3-MeHis excretion among the three groups over any period, except for the difference between the $a d l i b$. and the restricted groups during the third period $(p<0.05)$.

\section{Indices for the catabolic rate of muscle protein}

The 3-MeHis/SKM ratio of the ad lib. and food-restricted groups tended to 


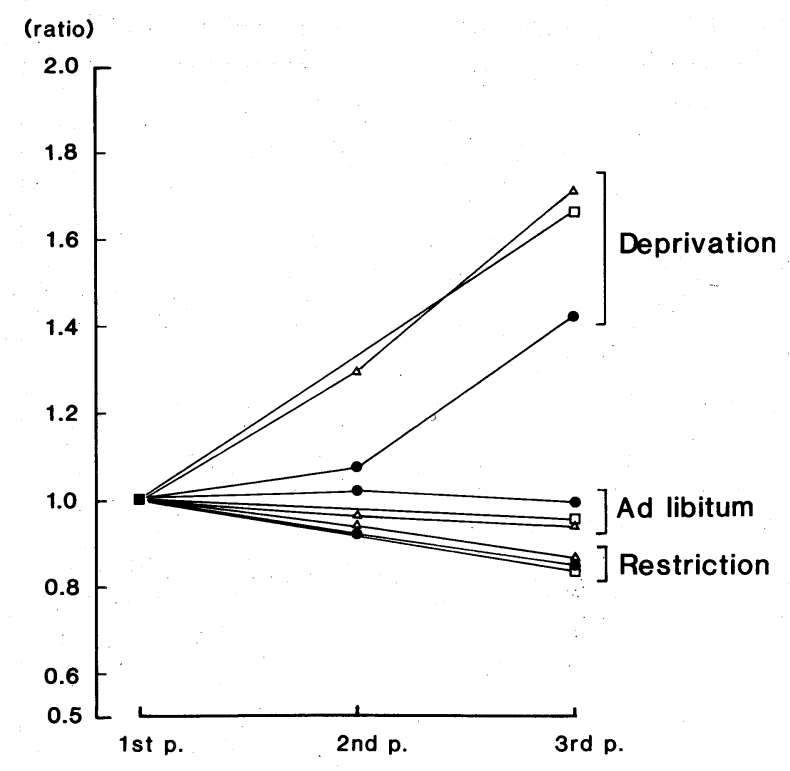

Fig. 3. Changes in the ratios of $3-\mathrm{MeHis} / \mathrm{CR}(\bullet)$, 3-MeHis/BW $(\triangle)$, and 3-MeHis/SKM $(\square)$ to the values of the control period. The data were expressed as the average values for 10 to 12 samples, except for the data of 3-MeHis/SKM during the third period, which was for 5 to 6 samples.

decrease slightly, while the ratio of the food-deprived group increased appreciably during the experimental period. Although the data of the 3-MeHis/CR and 3-MeHis/BW ratios naturally showed a trend similar to that of the 3-MeHis/SKM ratio, there was a slight difference between the results of the three indices: there was a statistically significant difference in the 3-MeHis/CR ratios between ad lib. group and the food-restricted group during the third period, but not in the 3-MeHis/SKM and 3-MeHis/BW ratios between these two groups during the same period (Fig. 2).

Figure 3 shows the ratios of the 3-MeHis/CR, 3-MeHis/BW, and 3-MeHis/SKM to those of the control period, comparing the change of those values during the experimental period in each group. The values of the 3-MeHis/CR were clearly lower than those of the other two indices during the second and third periods in the food-deprived group.

\section{DISCUSSION}

It is necessary to determine the total amount of muscle protein in estimating the fractional catabolic rate using the measurement of urinary 3-MeHis excretion. Muscle mass usually contains proteins at constant levels $(3,11)$, so SKM can be replaced as the amount of protein, regardless of the dietary conditions. However, 
it is not easy to determine the amount of SKM accurately. Thus, urinary CR is often measured as an index for estimating the approximate total amount of $\operatorname{SKM}(5,6)$. However, it has been known to be affected by factors such as age, sex, renal disease, etc. $(6,7,12-14)$. The results of the present study showed that the CR/SKM ratio was higher in the food-deprived group than in the other groups. The data put into question whether, in food deprivation, the CR excretion should be used for estimating SKM and for calculating 3-MeHis/CR ratio instead of the 3-MeHis/SKM ratio.

However, in the energy-restriction group, CR excretion was constant during the experimental period and the CR/SKM ratio was similar to that in the ad lib. group, indicating that $\mathrm{CR}$ excretion as well as BW can be used an index for SKM as far as the $a d l i b$. and energy-restricted rats are concerned. Therefore, it is valid to use the 3-MeHis/CR, instead of 3-MeHis/SKM, to compare the catabolic rate of muscle protein between the $a d$ lib. and the energy-restricted rats.

In this study, however, the energy-restriction group showed difference in statistical results between the changes in 3-MeHis/CR and the 3-MeHis/SKM during the experimental period. The divergence is due to the fact that there was a difference in the number of samples used for the calculation between the 3-MeHis/CR and the 3-MeHis/SKM. If the data for SKM were obtained from all of the rats examined for CR excretion and those were used for calculation of the 3-MeHis/SKM, the result of the 3-MeHis/SKM would be expected to be similar to that of the 3-MeHis/CR.

In addition, we observed that the total weight of the SKM closely correlated with urinary CR excretion, as expected, but this value correlated more with body weight than with urinary CR excretion. These results suggest that the body weight can be a better index for SKM than CR excretion under similar conditions as outlined in this study. However, the high correlation of BW with SKM may depend on the fact that young adult rats, which are not obese, were used in this study. Hence, the above results do not demonstrate that BW can be used as an index for SKM under all conditions.

The results of the present study showed that food deprivation caused an increase in the fractional catabolic rate of muscle protein. These results are consistent with previously reported findings (15-19). By the present results, we could not conclude that there was a significant difference between the protein breakdown of the ad lib. group and the food-restriction group. However, the data of the three indices showed that the catabolic rate of muscle protein tended to decrease when food intake was restricted. Since the difference of averaged value of each index between the two groups was slightly larger at the third period (day 20) than at the second period (day 10), statistical significance might have been obtained even in 3-MeHis/SKM if food restriction had been prolonged. There are reports that energy restriction causes a decrease of catabolic rate of muscle protein $(20,21)$, although there is another finding that the catabolic rate was not influenced by energy restriction(2). These contrasting findings may be due to different experimental conditions including

Vol. 35, No. 3, 1989 
differences in the food-restriction period as well as differences in age, fat deposition, and protein intake level.

It was suggested from the results of the present study that the use of urinary CR excretion is valid for estimating SKM and for the calculation of 3-MeHis/CR instead of 3-MeHis/SKM as an index of catabolic rate of muscle protein, under the condition of energy restriction. However, since in a special condition like food deprivation the amount of SKM is probably overestimated by its increase of CR excretion, the catabolic rate estimated as the $3-\mathrm{MeHis} / \mathrm{CR}$ ratio has some risk of underestimation.

\section{REFERENCES}

1) Munro, H. N., and Young, V. R. (1981): Use of $N^{\tau}$-methylhistidine excretion as an in vivo measure of myofibrillar protein breakdown, in Nitrogen Metabolism in Man, ed. by Waterlow, J. C., and Stephen, J. M. L., Applied Science Publisher, London, pp. 495-508.

2) Nishizawa, N. (1983): Development and its application of a method to estimate catabolic rate of myofibrillar proteins by measuring urinary excretion of $N^{\tau}$-methylhistidine. Nippon Eiyō Shokuryō Gakkaishi (J. Jpn. Soc. Nutr. Food Sci.), 36, 409-423.

3) Rikimaru, T., Yamamoto, S., Maeda, K., and Inoue, G. (1979): Effects of protein deficiency on muscle myofibrillar protein turnover in adult rats. J. Nutr. Sci. Vitaminol., 26, 39-57.

4) Young, V. R., Haverberg, L. N., Bilmazes, C., and Munro, H. N. (1973): Potential use of 3-methylhistidine excretion as an index of progressive reduction in muscle protein catabolism during starvation. Metabolism, 22, 1429-1436.

5) Schutte, J. E., Longhurst, J. C., Gaffney, F. A., Bastian, B. C., and Blomqvist, C. G. (1981): Total plasma creatinine: an accurate measure of total striated muscle mass. $J$. Appl. Physiol., 51, 762-766.

6) Heymsfield, S. B., Arteaga, C., McManus, C., Smith, J., and Moffitt, S. (1983): Measurement of muscle mass in humans: validity of the 24-hour urinary creatinine method. Am. J. Clin. Nutr., 37, 478-494.

7) Heymsfield, S. B., and Williams, P. J. (1988): Nutritional assessment by clinical and biochemical methods, in Modern Nutrition in Health and Disease, ed. by Shils, M. E., and Young, V. R., Lea \& Febiger, Philadelphia, pp. 817-860.

8) American Institute of Nutrition (1978): Report of the American Institute of Nutrition Ad Hoc Committee on standards for nutritional studies. J. Nutr., 107, 1340-1348.

9) Koishi, H. (1962): A critical examination on the Folin's method for determination of creatinine concentration in the urine. Osaka City Med. J., 8, 1-15.

10) Long, C. L., and Geiger, J. W. (1975): A rapid ion exchange method for quantitation of the urinary excretion of 3-methylhistidine. Biochem. Med., 12, 267-273.

11) Ashley, J. H., and Fisher, H. (1967): Protein reserves and muscle constituents of protein-depleted and repleted cocks. Br. J. Nutr., 21, 661-670.

12) Mitch, W. E., and Walser, M. (1978): A proposed mechanism for reduced creatinine excretion in severe chronic renal failure. Nephron, 21, 248-254.

13) Scrimshaw, N. S., Habicht, Jean-P., Piché, M. L., Cholakos, B., and Arroyave, G. (1966): Protein metabolism of young men during university examinations. Am. J. Clin. Nutr., 18, 321-324. 
14) Crim, M. C., Calloway, D. H., and Margen, S. (1976): Creatinine metabolism in men: creatinine pool size and turnover in relation to creatinine intake. J. Nutr., 106, 371-381.

15) $\mathrm{Li}$, J. B., and Goldberg, A. L. (1976): Effects of food deprivation on protein synthesis and degradation in rat skeletal muscles. Am. J. Physiol., 231, 441-448.

16) Millward, D. J., Garlick, P. J., Nnanyelugo, D. O., and Waterlow, J. C. (1976): The relative importance of muscle protein synthesis and breakdown in the regulation of muscle mass. Biochem. J., 156, 185-188.

17) Nishizawa, N., Shimbo, M., Noguchi, T., Hareyama, S., and Funabiki, R. (1978): Effect of starvation, refeeding and hydrocortisone administration on turnover of myofibrillar proteins estimated by urinary excretion of $N^{\tau}$-methylhistidine in the rat. Agric. Biol. Chem., 42, 2083-2089.

18) Lowell, B. B., Ruderman, N. B., and Goodman, M. N. (1986): Regulation of myofibrillar protein degradation in rat skeletal muscle during brief and prolonged starvation. Metabolism, 35, 1121-1127.

19) Garlick, P. J., Millward, D. J., James, W. P. T., and Waterlow, J. C. (1975): The effect of protein deprivation and starvation on the rate of protein synthesis in tissues of the rat. Biochim. Biophys. Acta, 414, 71-84.

20) Waterlow, J. C., Garlick, P. J., and Millward, D. J. (1978): The effects of nutrition and hormones on protein turnover in muscle, in Protein Turnover in Mammalian Tissues and in the Whole Body, North-Holland Publishing Company, Amsterdam, pp. 625-695.

21) Haverberg, L. H., Deckelbaum, L., Bilmazes, C., Munro, H. N., and Young, V. R. (1975): Myofibrillar protein turnover and urinary $N^{\tau}$-methylhistidine output; response to dietary supply of protein and energy. Biochem. J., 152, 503-510. 